\title{
Chronic pancreatitis: controversies in etiology, diagnosis and treatment
}

\author{
P. Draganov and P. P. Toskes \\ Division of Gastroenterology, Hepatology and Nutrition. University of Florida. Gainesville, Florida. USA
}

Draganov $P$, Toskes PP. Chronic pancreatitis: controversies in etiology, diagnosis and treatment. Rev Esp Enferm Dig 2004; 96: 649-659.

\begin{abstract}
The pathogenesis of idiopathic chronic pancreatitis remains poorly understood despite the high expectations for ascribing the pancreatic damage in affected patients to genetic defects. Mutations in the cationic trypsinogen gene, pancreatic secretory trypsin inhibitor, and the cystic fibrosis conductance regulator gene do not account for the chronic pancreatitis noted in most patients with idiopathic chronic pancreatitis. Small duct chronic pancreatitis can be best diagnosed with a hormone stimulation test. Endoscopic ultrasonography can detect abnormalities in both the parenchyma and ducts of the pancreas. The true value of endoscopic ultrasonography in diagnosing small duct chronic pancreatitis remains to be fully defined and is under active investigation. It is not clear whether endoscopic ultrasonography is more sensitive for early structural changes in patients with small duct disease or is over diagnosing chronic pancreatitis. Pancreatic enzyme supplementation with non-enteric formulation along with acid suppression (H2 blockers or proton pump inhibitors) is an effective therapy for pain in patients with small duct chronic pancreatitis. The role of endoscopic ultrasonography-guided celiac plexus block should be limited to treating those patients with chronic pancreatitis whose pain has not responded to other modalities. Total pancreatectomy followed by autologous islet cell autotransplantation appears to be potential therapeutic approach but for now should be considered experimental.
\end{abstract}

Recibido: 16-06-04.

Aceptado: 30-06-04.

Correspondencia: Peter Draganov. Assistant Professor of Medicine. University of Florida. 1600 SW Archer Rd. Division of Gastroenterology, Hepatology and Nutrition. Room HD 602, PO Box 100214. Gainesville, FL 001-32610-0214. Tel: 001-352-392-5046. Fax: 001-352-392-3618. email:dragapv@medicine.ufl.edu
Key words: Chronic pancreatitis. Abdominal pain. Endoscopic ultrasonography. Islet cell autotransplantation.

\section{INTRODUCTION}

Chronic pancreatitis (CP) is one of the greatest challenges in gastroenterology. The etiology of $\mathrm{CP}$ remains elusive in 10-30\% of all cases (1). A variety of diagnostic tests are available, the clear implication being that no one diagnostic test is sufficient to make the diagnosis in all patients with chronic pancreatitis (2). Once CP is diagnosed, a number of therapeutic options are available. This review of chronic pancreatitis focuses on selected controversial issues of etiology, diagnosis and management of CP.

\section{ETIOLOGY}

Despite the perhaps unreasonable expectations, it is becoming quite clear that most cases of idiopathic $\mathrm{CP}$ represent a complex interaction of genetic and environmental factors rather than resulting from single gene mutation. Neither mutations in the cationic trypsinogen gene $(3,4)$ nor mutations of the cystic fibrosis conductance regulator gene $(5,6)$ account for the chronic pancreatitis noted in most patients with idiopathic CP.

\section{Mutations involving the cationic trypsinogen gene}

Various mutations on the cationic trypsinogen gene (also known as protease serine 1 or PRSS1) have been identified. The first mutation identified in patients with hereditary pancreatitis was a single point mutation in the third exon of the cationic trypsinogen gene (3). This same mutation is called $\mathrm{R} 117 \mathrm{H}$ or $\mathrm{R} 122 \mathrm{H}$ in various publications (using two different nomenclatures). It was hypothesized that a single amino acid substitution led to a gain of function mutation, in which 
the mutated trypsin was resistant to inactivation once activated. Under normal conditions, human trypsinogen undergoes a slow autoactivation. Pancreatitis does not occur due to the presence of several protective mechanisms. Pancreatic secretory trypsin inhibitors are able to inhibit the activity of trypsin within the acinar cells and pancreatic duct. Once activated, trypsin may also be inactivated by cleavage at the 117 (or 122, depending on nomenclature) site. The R117H mutation appears to interfere with this inactivation of trypsin once activated. If trypsin is activated within the pancreas at levels sufficient to overwhelm the pancreatic secretory trypsin inhibitors that are present, and if this trypsin is resistant to inactivation by other protective mechanisms, the activated trypsin could activate other proenzymes and produce pancreatitis. This could produce chronic pancreatitis by repeated low-grade pancreatic injury from the activated proteases.

Two other, less frequent mutations (N29I and A16V) may also make trypsin resistant to inactivation $(7,8)$. Other mutations that involve the trypsinogen activation peptide (K23R, D22G), cationic trypsinogen promoter (-delTCC), and cationic trypsinogen gene (L104P, R116C, C139F) have been described (9-11). The penetrance of the best studied mutation $\mathrm{R} 122 \mathrm{H}$ is only $80 \%$ raising the question of the contribution from environmental factors to the development of hereditary $\mathrm{CP}$. On the other hand a number of studies have failed to show that mutations in the cationic trypsinogen gene are responsible for cases of nonfamilial sporadic idiopathic CP or contribute to the development of alcohol induced CP (11).

\section{Mutations involving the pancreatic secretory trypsin inhibitor gene}

The pancreatic secretory trypsin inhibitor (frequently referred in publications as Serine Protease Inhibitor Kazai Type 1 or SPINK 1) is believed to be the first line of defense against injury from activated trypsin within the pancreatic gland. A number of SPINK 1 mutations have been described the most common being N34S (12). The N34S mutation has been demonstrated in $25 \%$ of patients with familial pancreatitis (13), $16 \%$ of patients with idiopathic pancreatitis (11) and in 20 to $33 \%$ of patients with tropical pancreatitis $(14,15)$. The frequency of SPINK 1 mutations was not increased in patients with alcoholic CP (16).

\section{Mutations involving the cystic fibrosis gene}

At present it remains unclear whether the cystic fibrosis conductance regulator gene mutations alone can lead to pancreatitis as an autosomal recessive disease or if these mutations operate as part of a polygenic process affecting the susceptibility for developing CP. Cystic fibrosis conductance regulator gene mutations are common in the general population. A recent study tested 39 patients with idiopathic non-familial CP for common cystic fibrosis gene and pancreatic secretory trypsin inhibitor (SPINK 1) mutations (17).
Pancreatitis risk was increased approximately 40-fold by having 2 cystic fibrosis mutations ( $\mathrm{p}<0.0001$ ), 20-fold by having N34S ( $p<0.0001)$, and 900-fold by having both $(\mathrm{p}<$ $0.0001)$.

It appears that the role of genetic factors in the pathophysiology of CP is variable and complex. Numerous genetic, dietary and environmental factors probably act together to determine each individual susceptibility to develop CP. At present we are at the very early stages of identifying these factors and determining their precise role.

\section{DIAGNOSIS}

An impressive number and variety of diagnostic tests for $\mathrm{CP}$ have been developed. These diagnostic tests are usually separated into those tests that detect abnormalities of pancreatic function and those that detect abnormalities of pancreatic structure. A large number of patients exist who are thought to have idiopathic chronic pancreatitis but are not able to be diagnosed by the tests of structure including conventional abdominal ultrasound (US), computed tomography (CT), magnetic resonance cholangiopancreatography (MRCP), or endoscopic retrograde cholangiopancreatography (ERCP) (18). These patients are frequently referred as having small duct chronic pancreatitis (19). What percentage of all patients with chronic pancreatitis this subset represents remains controversial but may be as high as $40 \%$ at some centers.

Direct hormonal stimulation tests have been felt to be the most sensitive tests for chronic pancreatitis (20). The reliability of the secretin stimulation test in detecting chronic pancreatitis has been evaluated against histology in over 100 patients by Hayakawa et al. (21). In this study, the peak bicarbonate concentration of pancreatic secretion was the most accurate parameter for the diagnosis of CP. Although it has been widely accepted that the most sensitive and specific test to diagnose $\mathrm{CP}$ is a hormone stimulation test like the secretin test, this test has not been widely used (2). Multiple factors may have contributed to that. The procedure is labor and time intensive, demands trained personnel and a designated laboratory. A passage of a large size (26 Fr) oroduodenal tube is required. The tube has to remain in place for more than one hour because the standard secretin stimulation test in our laboratory requires collection of pancreatic secretions for 60 minutes after injection with secretin. During the insertion of the tube and during sample collection sedation is not used because it can interfere with the test results. The lack of sedation can make the performance of the secretin stimulation test uncomfortable for patients. A significant degree of discomfort rarely may prevent successful completion of the test.

The search continues for a simple, inexpensive, safe, and accurate test to detect structural changes related to chronic pancreatitis. In recent years, endoscopic ultrasonography (EUS) has emerged as the frontrunner among the tests evaluating pancreatic structure. There are distinct advantages of endoscopic ultrasonography in imaging the pancreas. Transabdominal US imaging suffers from low resolution because high-frequency instruments providing high resolution do not 
penetrate deeply enough to image the pancreas from the skin surface. Furthermore, transabdominal ultrasound is limited by overlying bowel gas. EUS overcomes both of these disadvantages by placing a transducer within the lumen of the bowel in close proximity with the pancreas and removes or displaces bowel gas. Also, endoscopic ultrasonography is significantly safer than ERCP. Overall, the rate of serious complications from diagnostic endoscopic ultrasonography is one per 2000 procedures (22). Finally, whereas ERCP can image only the pancreatic ductal system, endoscopic ultrasonography can evaluate both the pancreatic ducts and the parenchyma.

Nonetheless, there are also several disadvantages of endoscopic ultrasonography. First, in the United States, EUS still remains confined to very few tertiary care centers and is not widely available. Second, the value of endoscopic ultrasonography is directly proportional to the training, skill, and experience of the endosonographer. All of the published information pertaining to EUS is the work of a relatively small group of experts. Third, the principal concern in using EUS for the diagnosis of chronic pancreatitis is the possibility that it may over diagnose chronic pancreatitis, causing patients to be falsely diagnosed with $\mathrm{CP}$ when they do not have pancreatic disease. Because experts cannot agree on a gold standard for the diagnosis of chronic pancreatitis, it has been difficult to determine the extent to which over diagnosis occurs. In patients with endoscopic ultrasonographic evidence of changes of chronic pancreatitis but a normal secretin test or a normal ERCP, it is not clear whether the endoscopic ultrasonography is more sensitive for early changes or if it is truly over diagnosing chronic pancreatitis (20).

In the past, a number of studies have compared EUS with various diagnostic modalities. Comparison with function testing and pancreatography obtained via ERCP shows similar results. The main source of disagreement in these studies involved patients with abnormal results of endoscopic ultrasonography and normal function tests or normal ERCP. More recently, EUS was directly compared with the secretin test. The secretin test was used as a gold standard in 21 patients with unexplained abdominal pain. The two endosonographers were blinded to the results of the secretin test. When a cutoff of four criteria for chronic pancreatitis was used, the sensitivity of endoscopic ultrasonography was $57 \%$, and the specificity was $64 \%$. At any chosen cutoff, a substantial number of patients had discordant test results (23).

In general, histology is the most obvious candidate for a diagnostic gold standard. A number of factors have prevented histologic samples from being taken in the case of chronic pancreatitis. The distribution of changes of chronic pancreatitis can be patchy (24). Pancreatic tissue is difficult to obtain, and biopsy of the pancreas is associated with potential risk. Can a technique be developed that can reliably diagnose chronic pancreatitis from needle biopsy samples rather than requiring surgical resection, specimens, or core biopsy samples? Hollerbach et al. attempted to answer this question (25). They prospectively evaluated 37 patients with clinical symptoms and laboratory test results suggestive of chronic pancreatitis. All patients underwent ERCP, indirect pancreatic function testing (fecal chymotrypsin, fecal pancreatic elastase 1, urinary pancreolauryl test), and endoscopic ultrasonography. Twenty-seven underwent fine-needle aspiration (FNA) guided by endoscopic ultrasonography. Thirty-one patients were shown to have chronic pancreatitis on ERCP, and 33 were shown to have chronic pancreatitis on endoscopic ultrasonography. Endoscopic ultrasonography had a sensitivity of $97 \%$, a specificity of $60 \%$, and a negative predictive value of $75 \%$ if ERCP served as the gold standard for the diagnosis of chronic pancreatitis. FNA findings increased the negative predictive value to $100 \%$, resulting in a small increase in specificity to $67 \%$. There is poor correlation between endoscopic ultrasonography and indirect function testing, particularly in patients with mild disease. Based on the available findings, FNA cannot be recommended as a routine diagnostic extension of EUS in the diagnosis of CP.

At present, EUS is an important tool in the diagnosis of chronic pancreatitis. There is still controversy regarding the diagnosing of early (small duct) chronic pancreatitis based on endoscopic ultrasonography changes alone. In such cases, one would be well advised to take into account all components of the patient's evaluation, including history, pancreatic function testing, and responsive response to therapy, before diagnosing the patient with chronic pancreatitis (20).

\section{THERAPY}

Patients with chronic pancreatitis seek medical attention predominantly secondary to two symptoms: abdominal pain and maldigestion. At present we have an effective therapy for maldigestion in the form of pancreatic enzymes supplementation. On the other hand therapy of pain can be a real challenge to patients and physicians alike. Three pathophysiologic mechanisms have been proposed to explain the pain in CP: acute pancreatic inflammation, increased intrapancreatic pressure, and alterations in pancreatic nerves. Different therapies for CP aim to decrease pain by influencing one of the above mechanisms. Therapy with antioxidants aims to decrease pancreatic inflammation. Pancreatic enzyme supplementation, cholecystokinin (CCK) antagonists, and octreotide aim to decrease pancreatic secretion thus decreasing intrapancreatic pressure. Various endoscopic and surgical techniques attempt to decrease the pressure by providing improved drainage. Celiac plexus block and thoracoscopic splanchnicectomy interrupt neural transmission of pain signals. A relatively new radical approach is to perform pancreatectomy with islet cell autotransplantation. Few therapies have been studied in placebo-controlled trials of adequate sample size, and advocates of specific therapies often forget the substantial placebo response of $35-40 \%$ that can be seen in these patients (26). Below we will address the use of pancreatic enzyme supplementation, EUS guided celiac plexus block, and pancreatectomy with islet cell autotransplantation as therapies for pain due to chronic pancreatitis. 


\section{The role of pancreatic enzyme supplementation as a therapy for pain due to chronic pancreatitis}

It is important to realize that chronic pancreatitis is not one disease, but may have many forms. The differentiation between those patients with chronic pancreatitis and big duct disease and those with chronic pancreatitis and small duct disease is an attempt to tailor the therapeutic approach towards these different groups of patients (19). It is likely that, with the recognition that a CCK releasing factor is important in the feedback control of pancreatic secretion, an appreciation is emerging that there may be forms of pancreatitis that are related to abnormalities in CCK homeostasis (27). Oral pancreatic enzyme preparations appear to inhibit pancreatic exocrine secretion through negative feedback mechanism involving intraduodenal serine proteases and the exocrine pancreas. Intraduodenal serine proteases modulate pancreatic exocrine secretion by regulating CCK release. Because patients with chronic pancreatitis often have decreased intraduodenal protease activity secondary to a damaged gland, they may not be capable of inactivating the intraduodenal peptide (CCK releasing peptide) that stimulates CCK blood levels. Hence, in a subset of patients, the gland is under constant stimulation by CCK. Oral pancreatic enzyme supplements may provide relief of pain by supplementing endogenous protease inactivation of CCK releasing peptide, in patients with chronic pancreatitis pain. Inactivation of this peptide results in decreased CCK release, which decreases pancreatic stimulation, hence may decrease pain. Because this is a proximal small intestine phenomenon, it is mandatory that the pancreatic proteases be delivered to the upper small intestine. This can only be done consistently by the administration of non-enteric coated pancreatic enzyme preparations. Because the non-enteric coated enzyme preparations are not protected against gastric acid in the pass through the stomach, it is appropriate to add an acid-suppressing agent $(\mathrm{H} 2$ receptor antagonist or proton pump inhibitor), to allow significant amount of the protease to reach the duodenum. From our clinical experience we have found that Viokase-16 (Axcan Scandipharm, Birmingham, AL) given orally at a dose of 4 tablets with each meal and at bedtime, provides the best clinical response in most patients.

Six randomized trials have evaluated the effectiveness of pancreatic enzymes in reducing the pain of chronic pancreatitis (28). Pancreatic enzymes were effective in reducing pain in two trials $(29,30)$, whereas in 4 studies no statistical improvement in relieving pain was seen. Given our understanding of CCK regulation of pancreatic secretion and mechanism of action of pancreatic enzymes, not surprisingly, the two trials showing positive effect in reducing pain used non-enteric coated preparations and all trials showing no improvement used enteric coated enzymes. Furthermore in patients with big duct disease there was at best a $25 \%$ response rate in decreasing abdominal pain, whereas in those with small duct disease there was a response rate of approximately $70 \%$. Results of a meta-analysis of these randomized trials indicated that pancreatic enzyme therapy did not decrease abdominal pain in patients with chronic pancreatitis (31). This meta-analysis, however, has come under criti- cism because it lumped together the analysis of those patients receiving non-enteric coated enzymes and entericcoated enzymes (20).

Abundant information now exists, both in randomized trials and clinical experience, indicating that non-enteric coated enzyme preparations are preferable over entericcoated enzymes for relief of abdominal pain in patients with chronic pancreatitis. Thus, if pancreatic enzyme preparations are to be employed to relieve the pain of chronic pancreatitis, then the appropriate patient should be selected, i.e., one with small duct disease and the appropriate enzyme preparations should be employed, i.e., a non-enteric coated enzyme preparation in the proper dose. Great success is not going to be achieved if one attempts to treat the pain of a patient with big duct disease and steatorrhea with an entericcoated preparation.

\section{The role of EUS guided celiac plexus block as a therapy for pain due to chronic pancreatitis}

A substantial body of literature has accumulated regarding EUS-guided celiac plexus block in the management of pain resulting from pancreatic cancer. A combination of long-acting local anesthetics and steroids injected into the celiac plexus under endoscopic ultrasonography guidance in patients with $\mathrm{CP}$ has been used for years (personal communication), yet the published data are scarce. Gress $\mathrm{F}$ et al. compared endoscopic ultrasonography-guided versus $\mathrm{CT}$ guided celiac blocks in a prospective, randomized fashion (32). The conclusion of this small study was that EUS-guided celiac block $(n=10)$ provided more persistent pain relief than CT-guided block $(n=8)$. The same group of investigators recently published their prospective experience with endoscopic ultrasonography-guided celiac plexus block in 90 patients with pain resulting from chronic pancreatitis (33). A significant improvement in pain score occurred in 55\% of the patients. The benefit persisted beyond 12 weeks in $26 \%$ of patients and beyond 24 weeks in only $10 \%$.

The current evidence indicates that endoscopic ultrasonography-guided celiac plexus block is safe and well tolerated, with excellent temporary results in some patients. Unfortunately, reliable predictors of success are lacking. In the absence of long-term studies with follow-up in patients with chronic pancreatitis whose pain is chronic, the role of endoscopic ultrasonography-guided celiac plexus block should be limited to treating flares of chronic pain in patients with otherwise limited therapeutic options.

\section{The role of pancreatectomy with islet cell autotransplantation as a therapy for pain due to chronic pancreatitis}

Total pancreatectomy, as a therapy for severe chronic pancreatitis provides good pain control but has been plagued with long-term morbidity and mortality, in particular, related to the ensuing diabetes mellitus $(34,35)$. An elegant alternative is to perform total or nearly total pancreatectomy fol- 
lowed by islet cell autotransplantation. This attractive approach comes with the high expectations that after removing the diseased pancreas pain control will be achieved without paying the price of causing surgical diabetes.

Recently three studies have examined the outcomes of patients undergoing total pancreatectomy followed by autologous islet cell autotransplantation. Twenty two patients underwent the procedure at the University of Cincinnati from February 2000 to February 2003 (36). There were 4 major post-operative complications (acute respiratory distress syndrome, intra-abdominal abscess and pulmonary embolism) and no deaths. All patients were taking opioid analgesics prior to the intervention. After mean follow-up of 19 months (range 3 to 41 ), $82 \%$ of the patients required no opioids analgesia. Forty one per cent were insulin independent and $27 \%$ required minimal amount of insulin.

The experience of the Leicester General Hospital in the United Kingdom was recently published (37). Forty patients underwent pancreatectomy with islet cell autotransplantation. The range of follow-up was from 6 months to 7 years. A crude estimation of pain control was done by reporting the use of opiates. Data were not available on all patients. At 6 months all patients for whom data are available $(n=6)$ still required narcotics. That number decreased to 5 out of 10 patients at one year, 4 out of 9 at two. Of the 4 patients followed for 6 years one patient was requiring opioids. Most importantly of the 40 patients, 38 required varying doses of insulin and only one had normal oral glucose tolerance test. The authors noted that over time the function of the islet cell transplant deteriorated.

The largest series to date comes from the University of Minnesota (38). Over a period of 28 years 112 islet cell autotransplants were done at the time of total or subtotal pancreatectomy for chronic pancreatitis. Pain resolved in $40 \%$ of the patients, improved in $32 \%$ and remained unchanged or worsened in $12 \%$. Complete insulin independence was achieved overall in $38 \%$ of the patients and $12 \%$ required only one injection daily with long-lasting insulin. Furthermore $71 \%$ of the patients who had not undergone previous pancreatic surgery did not require insulin. Not surprisingly, patients who had undergone prior distal pancreatectomy or Puestow drainage procedure had lower islet cell yield and less than $20 \%$ were insulin independent.

These studies show that islet cell autotransplantation is technically feasible. As this technology improves total pancreatectomy followed by autologous islet cell autotransplantation one day may become a standard therapy for patients suffering from refractory pain due to chronic pancreatitis.

\section{CONCLUSION}

The pathogenesis of idiopathic chronic pancreatitis remains poorly understood. Genetic mutations account for the minority of cases in patients with idiopathic chronic pancreatitis. The true value of endoscopic ultrasonography in diagnosing small duct chronic pancreatitis remains to be fully defined. Non-enteric coated pancreatic enzyme supplemen- tation is an effective therapy for patients with small duct chronic pancreatitis. Endoscopic ultrasonography-guided celiac plexus block can provide excellent short-term pain relief in some patients with chronic pancreatitis. Large, longterm controlled studies are needed to examine the safety and efficacy of celiac plexus block. At present its use should be limited to treating those patients with chronic pancreatitis whose pain has not responded to other modalities. Total pancreatectomy followed by autologous islet cell autotransplantation appears to be a feasible therapeutic approach but for now should be consider experimental.

\section{REFERENCES}

1. Banks PA. Acute and chronic pancreatitis. In: Feldman M, Scharschmidt BF, Sleisenger MH, eds. Gastrointestinal and liver disease: pathophysiology/diagnosis/management. 6th ed. Philadelphia: WB Saunders, 1998. p. 809-62.

2. Chowdhury RS, Forsmark CE. Review article: Pancreatic function testing. Aliment Pharmacol Ther 2003; 17: 733-50.

3. Whitcomb DC, Gorry MC, Preston RA, Furey W, Sossenheimer MJ, Ulrich $C D$, et al. Hereditary pancreatitis is caused by a mutation in the cationic trypsinogen gene. Nat Genet 1996; 14: 141-5.

4. Whitcomb DC. Genetic predispositions to acute and chronic pancreatitis. Med Clin North Am 2000; 84: 531-47, vii.

5. Cohn JA, Friedman KJ, Noone PG, Knowles MR, Silverman LM, Jowell PS. Relation between mutations of the cystic fibrosis gene and idiopathic pancreatitis. N Engl J Med 1998; 339: 653-8.

6. Sharer N, Schwarz M, Malone G, Howarth A, Painter J, Super M, et al. Mutations of the cystic fibrosis gene in patients with chronic pancreatitis. N Engl J Med. 1998; 339: 645-52.

7. Gorry MC, Gabbaizedeh D, Furey W, Gates LK Jr, Preston RA, Aston $\mathrm{CE}$, et al. Mutations in the cationic trypsinogen gene are associated with recurrent acute and chronic pancreatitis. Gastroenterology 1997; 113: 1063-8.

8. Witt H, Luck W, Becker M. A signal peptide cleavage site mutation in the cationic trypsinogen gene is strongly associated with chronic pancreatitis. Gastroenterology 1999; 117: 7-10.

9. Ferec C, Raguenes O, Salomon R, Roche C, Bernard JP, Guillot M, et al. Mutations in the cationic trypsinogen gene and evidence for genetic heterogeneity in hereditary pancreatitis. J Med Genet 1999; 36: 228-32.

10. Teich N, Ockenga J, Hoffmeister A, Manns M, Mossner J, Keim V. Chronic pancreatitis associated with an activation peptide mutation that facilitates trypsin activation. Gastroenterology 2000; 119: 461-5.

11. Teich N, Bauer N, Mossner J, Keim V. Mutational screening of patients with nonalcoholic chronic pancreatitis: identification of further trypsinogen variants. Am J Gastroenterol 2002; 97: 341-6.

12. Witt H, Luck W, Hennies HC, Classen M, Kage A, Lass U, et al. Mutations in the gene encoding the serine protease inhibitor, Kazal type 1 are associated with chronic pancreatitis. Nat Genet 2000; 25: 213-6.

13. Pfutzer RH, Barmada MM, Brunskill AP, Finch R, Hart PS, Neoptolemos J, et al. SPINK1/PSTI polymorphisms act as disease modifiers in familial and idiopathic chronic pancreatitis. Gastroenterology 2000; 119: 615-23.

14. Schneider A, Suman A, Rossi L, Barmada MM, Beglinger C, Parvin $\mathrm{S}$, et al. SPINK1/PSTI mutations are associated with tropical pancreatitis and type II diabetes mellitus in Bangladesh. Gastroenterology 2002; 123: 1026-30.

15. Hassan Z, Mohan V, Ali L, Allotey R, Barakat K, Faruque MO, et al. SPINK1 is a susceptibility gene for fibrocalculous pancreatic diabetes in subjects from the Indian subcontinent. Am J Hum Genet 2002; 71: 964-8.

16. Schneider A, Pfutzer RH, Barmada MM, Slivka A, Martin J, Whitcomb DC. Limited contribution of the SPINK1 N34S mutation to the risk and severity of alcoholic chronic pancreatitis: a report from the United States. Dig Dis Sci 2003; 48: 1110-5. 
17. Noone PG, Zhou Z, Silverman LM, Jowell PS, Knowles MR, Cohn JA. Cystic fibrosis gene mutations and pancreatitis risk: relation to epithelial ion transport and trypsin inhibitor gene mutations. Gastroenterology 2001; 121: 1310-9.

18. Forsmark CE. The diagnosis of chronic pancreatitis. Gastrointest Endosc 2000; 52: 293-8.

19. Singh VV, Toskes PP. Medical therapy for chronic pancreatitis pain. Curr Gastroenterol Rep 2003; 5: 110-6.

20. Draganov P, Toskes PP: Chronic pancreatitis. Curr Opin Gastroenterol 2002, 18: 558-62.

21. Hayakawa T, Kondo T, Shibata T, Noda A, Suzuki T, Nakano S. Relationship between pancreatic exocrine function and histological changes in chronic pancreatitis. Am J Gastroenterol 1992; 87: 1170-4.

22. Williams DB, Sahai AV, Aabakken L, Penman ID, van Velse A, Webb J, et al. Endoscopic ultrasound guided fine needle aspiration biopsy: a large single centre experience. Gut 1999; 44: 720-6.

23. Chowdhury RS, Bhutani MS, Mishra G, et al. Comparative analysis of pancreatic function testing versus morphologic assessment (by EUS) for the evaluation of chronic unexplained abdominal pain. Gastroenterology 2001, 120: A-647.

24. Walsh TN, Rode J, Theis BA, Russell RC. Minimal change chronic pancreatitis. Gut 1992; 33: 1566-71.

25. Hollerbach S, Klamann A, Topalidis T, Schmiegel WH. Endoscopic ultrasonography (EUS) and fine-needle aspiration (FNA) cytology for diagnosis of chronic pancreatitis. Endoscopy 2001; 33: 824-31.

26. Toskes PP, Forsmark CE, Demeo MT, et al. A multicenter controlled trial of octreotide for the pain of chronic pancreatitis (abstract). Pancreas 8: 774, 1993.

27. Chey WY. Neurohormonal control of the exocrine pancreas. Curr Opin Gastroenterol 1997, 13: 375-80.

28. Warshaw AL, Banks PA, Fernandez-Del Castillo C. AGA technical review: treatment of pain in chronic pancreatitis. Gastroenterology 1998; 115: 765-76.

29. Isaksson G, Ihse I. Pain reduction by an oral pancreatic enzyme pre- paration in chronic pancreatitis. Dig Dis Sci 1983; 28: 97-102.

30. Slaff J, Jacobson D, Tillman CR, Curington C, Toskes P. Proteasespecific suppression of pancreatic exocrine secretion. Gastroenterology 1984; 87: 44-52.

31. Brown A, Hughes M, Tenner S, Banks PA. Does pancreatic enzyme supplementation reduce pain in patients with chronic pancreatitis: a meta-analysis. Am J Gastroenterol 1997; 92: 2032-5.

32. Gress F, Schmitt C, Sherman S, Ikenberry S, Lehman G. A prospective randomized comparison of endoscopic ultrasound- and computed tomography-guided celiac plexus block for managing chronic pancreatitis pain. Am J Gastroenterol 1999; 94: 900-5.

33. Gress F, Schmitt C, Sherman S, Ciaccia D, Ikenberry S, Lehman G. Endoscopic ultrasound-guided celiac plexus block for managing abdominal pain associated with chronic pancreatitis: a prospective single center experience. Am J Gastroenterol 2001; 96: 409-16.

34. Evans JD, Wilson PG, Carver C, Bramhall SR, Buckels JA, Mayer $\mathrm{AD}$, et al. Outcome of surgery for chronic pancreatitis. Br J Surg 1997; 84: 624-9.

35. Berney T, Rudisuhli T, Oberholzer J, Caulfield A, Morel P. Longterm metabolic results after pancreatic resection for severe chronic pancreatitis. Arch Surg 2000; 135: 1106-11.

36. Rodriguez Rilo HL, Ahmad SA, D’Alessio D, Iwanaga Y, Kim J, Choe KA, et al. Total pancreatectomy and autologous islet cell transplantation as a means to treat severe chronic pancreatitis. J Gastrointest Surg 2003; 7: 978-89.

37. Clayton HA, Davies JE, Pollard CA, White SA, Musto PP, Dennison AR. Pancreatectomy with islet autotransplantation for the treatment of severe chronic pancreatitis: the first 40 patients at the Leicester general hospital. Transplantation 2003; 76: 92-8.

38. Gruessner RW, Sutherland DE, Dunn DL, Najarian JS, Jie T, Hering BJ, et al. Transplant options for patients undergoing total pancreatectomy for chronic pancreatitis. J Am Coll Surg 2004; 198: 559-67; discussion 568-9.

\title{
Pancreatitis crónica: controversias respecto a la etiología, el diagnóstico y el tratamiento
}

\author{
P. Draganov y P. P. Toskes \\ Sección de Gastroenterología, Hepatología y Nutrición. Universidad de Florida. Gainesville, Florida. EE.UU.
}

\section{RESUMEN}

La patogenia de la pancreatitis crónica idiopática sigue siendo poco conocida, a pesar de las expectativas de atribuir el daño pancreático que sufren los pacientes con esta enfermedad a factores genéticos. Las mutaciones del gen del tripsinógeno catiónico, del gen del inhibidor de la tripsina secretoria del páncreas y del gen regulador de conductancia de la fibrosis quística no explican la pancreatitis crónica de la mayoría de los pacientes con pancreatitis crónica idiopática. La mejor forma de diagnosticar una pancreatitis crónica de conductos pequeños es la prueba de estimulación hormonal. La ecografía endoscópica puede detectar anomalías tanto en el parénquima como en los conductos del páncreas. El verdadero valor de la ecoendoscopia en el diagnóstico de la pancreatitis crónica de conductos pequeños está aún por determinar y se está investigando activamente. No está claro si la ecografía endoscópica es más sensible a los cambios estructurales precoces de los pacientes con afectación de conductos pequeños o si sobrediagnostica la pancreatitis crónica. Los suplementos de enzimas pancreáticas de formulación no entérica, junto con la supresión ácida (bloqueadores $\mathrm{H} 2$ o inhibidores de la bomba de protones), constituyen un tratamiento eficaz del dolor en los pacientes con pancreatitis crónica de conductos pequeños. El papel del bloqueo del plexo celiaco guiado por ecografía endoscópica debe limitarse al tratamiento de aquellos pacientes con pancreatitis crónica cuyo dolor no responda a otras modalidades. Parece que la pancreatec- 
tomía total seguida de autotrasplante autólogo de células de los islotes podría representar un posible abordaje terapéutico, pero debe considerarse experimental por ahora.

Palabras clave: Pancreatitis crónica. Dolor abdominal. Ultrasonografía endoscópica. Autotrasplante de célula del islote.

\section{INTRODUCCIÓN}

La pancreatitis crónica (PC) representa uno de los mayores desafíos de la gastroenterología. La etiología de la PC sigue siendo difícil de establecer en el 10-30\% de todos los casos (1). Se dispone de diversas pruebas diagnósticas, lo que implica claramente que ninguna, por sí sola, basta para hacer el diagnóstico en todos los pacientes con pancreatitis crónica (2). Una vez diagnosticada la PC, existen varias opciones terapéuticas. Esta revisión de la pancreatitis crónica se centra en determinados aspectos controvertidos acerca de la etiología, el diagnóstico y el tratamiento de la PC.

\section{ETIOLOGÍA}

A pesar de ciertas expectativas quizá poco razonables, cada vez está más claro que la mayor parte de los casos de PC idiopática representan una compleja interacción de factores genéticos y ambientales, más que surgir de una sola mutación genética. Ni las mutaciones del gen del tripsinógeno catiónico $(3,4)$, ni las mutaciones del gen regulador de conductancia de la fibrosis quística $(5,6)$ explican la pancreatitis crónica que padecen la mayoría de los pacientes con PC idiopática.

\section{Mutaciones que afectan al gen del tripsinógeno catiónico}

Se han identificado diversas mutaciones en el gen del tripsinógeno catiónico (también llamado proteasa de serina 1 o PRSS1). La primera que se identificó en pacientes con pancreatitis hereditaria fue una mutación puntual en el tercer exón del gen del tripsinógeno catiónico (3). Esta misma mutación se denomina R117H o R122H en diversas publicaciones (se usan dos nomenclaturas distintas). Se propuso la hipótesis de que la sustitución de un solo aminoácido podría conducir a una mutación de ganancia funcional en la que la tripsina mutante fuera resistente a su inactivación, una vez activada. En condiciones normales, el tripsinógeno humano se autoactiva lentamente. No se produce ninguna pancreatitis gracias a la presencia de varios mecanismos protectores. Los inhibidores de la tripsina secretoria del páncreas son capaces de inhibir la actividad de la tripsina en el interior de las células acinares y del conducto pancreático. Una vez activada, la tripsina puede también inactivarse por escisión en el punto 117 (o 122, dependiendo de la nomenclatura). La mutación $\mathrm{R} 117 \mathrm{H}$ parece interferir con esta inactivación de la tripsina ya activada. Si la tripsina se activa dentro del páncreas hasta alcanzar niveles suficientes como para desbordar a los inhibidores de la tripsina secretoria pancreática presentes, y si esta tripsina es resistente a la inactivación por otros mecanismos de protección, la tripsina activada podría activar otras proenzimas y producir pancreatitis. Esto podría dar lugar a una pancreatitis crónica por la repetición de lesiones pancreáticas de grado leve provocadas por las proteasas activadas.

Otras dos mutaciones menos frecuentes (N29I y A16V) pueden hacer que la tripsina sea resistente a su inactivación $(7,8)$. Se han descrito otras mutaciones que afectan a los genes del péptido activador del tripsinógeno (K23R, D22G), del promotor del tripsinógeno catiónico (-delTCC) y del tripsinógeno catiónico (L104P, R116C, C139F) (9-11). La penetrancia de la mutación mejor estudiada, la R122H, es de sólo un $80 \%$, lo que suscita la cuestión de la contribución que realizan los factores ambientales al desarrollo de la PC hereditaria. Por otra parte, varios estudios no han logrado demostrar que las mutaciones del gen del tripsinógeno catiónico sean responsables de los casos de PC idiopática esporádica no familiar, ni que contribuyan a la aparición de la PC inducida por alcohol (11).

\section{Mutaciones que afectan al gen de la tripsina secretoria pancreática}

Se cree que el inhibidor de la tripsina secretoria pancreática (llamado con frecuencia inhibidor de la proteasa de serina Kazal de tipo 1 o SPINK 1) constituye la primera línea de defensa frente a las lesiones producidas por la tripsina activada en el interior del páncreas. Se han descrito varias mutaciones del SPINK 1, siendo la más frecuente de ellas la N34S (12). La mutación N34S se ha podido demostrar en el $25 \%$ de los pacientes con pancreatitis familiar (13), en el $16 \%$ de los pacientes con pancreatitis idiopática (11) y en el 20 a $33 \%$ de los pacientes con pancreatitis tropical $(14,15)$. La frecuencia de las mutaciones del SPINK 1 no era mayor en los pacientes con PC alcohólica (16).

\section{Mutaciones que afectan al gen de la fibrosis quística}

Actualmente sigue sin estar claro si las mutaciones del gen regulador de conductancia de la fibrosis quística pueden ellas solas producir pancreatitis de manera autosómica recesiva, o si pueden actuar formando parte de un proceso poligénico que afecte a la susceptibilidad de presentar una PC. Las mutaciones del gen regulador de conductancia de la fibrosis quística son frecuentes en la población general. En un estudio reciente se exploraron las mutaciones del gen de la fibrosis quística y del gen del inhibidor de la tripsina secretoria pancreática (SPINK1) en 39 pacientes con PC idiopática no familiar (17). El riesgo de pancreatitis aumentaba unas 40 veces si se tenían 2 mutaciones del gen de la fibrosis quística ( $<<0,0001), 20$ veces si se tenía la N34S ( $<<$ $0,0001)$ y 900 veces si se tenían ambas cosas $(\mathrm{p}<0,0001)$.

Parece que el papel desempeñado por los factores genéticos en la fisiopatología de la PC es variable y complejo. Probablemente haya numerosos factores genéticos, dietéti- 
$\cos$ y ambientales que, conjuntamente, determinen la susceptibilidad de cada individuo a la hora de desarrollar una PC. Actualmente nos encontramos en las fases más tempranas de la identificación de estos factores y de la determinación de sus papeles reales.

\section{DIAGNÓSTICO}

Se han desarrollado pruebas diagnósticas de la PC en cantidad y variedad impresionantes. Estas pruebas diagnósticas suelen separarse entre las que detectan anomalías de la función pancreática y aquellas que detectan anormalidades de la estructura del páncreas. Se cree que muchos enfermos padecen una pancreatitis crónica idiopática sin que las pruebas estructurales -como la ecografía abdominal convencional (ECO), la tomografía computarizada (TC), la colangiopancreatografía por resonancia magnética (CPRM) o la colangiopancreatografía endoscópica retrógrada (CPER)son capaces de reconocerla (18). Con frecuencia se dice que estos pacientes presentan una pancreatitis crónica de conductos pequeños (19). Sigue sin haber acuerdo respecto al porcentaje que supone este subconjunto entre todos los pacientes con pancreatitis crónica, pero, en algunos centros, podría llegar a ser de hasta un $40 \%$.

Se piensa que las pruebas de estimulación hormonal directa son las más sensibles para diagnosticar la pancreatitis crónica (20). La fiabilidad de la prueba de estimulación con secretina para detectar la pancreatitis crónica ha sido evaluada frente a la histología por Hayakawa y cols. en más de 100 pacientes (21). En este estudio, la concentración máxima de bicarbonato en la secreción pancreática fue el parámetro más preciso a la hora de diagnosticar la PC. Aunque está ampliamente aceptado que las pruebas más sensibles y específicas para diagnosticar la PC son las de estimulación hormonal, como la prueba de la secretina, esta no ha sido utilizada de manera generalizada (2). A ello pueden haber contribuido múltiples factores. El procedimiento es laborioso y consume mucho tiempo, requiere personal entrenado y precisa un laboratorio competente. Es necesario introducir una sonda oroduodenal de gran tamaño (26 Fr). La sonda ha de permanecer puesta durante más de una hora, pues la prueba de estimulación con secretina estándar requiere recoger la secreción pancreática durante 60 minutos tras la inyección de secretina. No se utiliza sedación durante la inserción del tubo ni durante la recogida de muestras, ya que puede interferir con los resultados de la prueba. La falta de sedación puede hacer que la realización de la prueba de estimulación con secretina resulte incómoda para el paciente. El importante nivel de incomodidad rara vez impide que la prueba culmine con éxito.

Se sigue buscando una prueba sencilla, barata, segura y precisa capaz de detectar los cambios estructurales relacionados con la pancreatitis crónica. En los últimos años, la ecografía endoscópica (USE) se ha convertido en la prueba principal para evaluar la estructura del páncreas. A la hora de obtener imágenes del páncreas, la ecografía endoscópica presenta ventajas características. La ECO transabdominal adolece de una baja resolución, ya que los instrumentos de alta frecuencia que aportan una alta resolución no penetran lo suficientemente desde la superficie de la piel como para obtener imágenes del páncreas. Además, la ecografía transabdominal se ve limitada por el gas intestinal suprayacente. La USE supera estos dos inconvenientes ya que sitúa el transductor dentro de la luz intestinal, muy cerca del páncreas, y elimina o desplaza el gas del intestino. La ecografía endoscópica también es significativamente más segura que la CPER. En conjunto, la tasa de complicaciones graves causadas por la USE es de una por cada 2000 intervenciones (22). Finalmente, mientras que la CPER sólo puede obtener imágenes del sistema ductal del páncreas, la ecografía endoscópica es capaz de evaluar tanto los conductos pancreáticos como el parénquima.

No obstante, la USE tiene también varias desventajas. En primer lugar, la USE sigue estando confinada en muy pocos centros de atención terciaria en Estados Unidos y no está disponible de manera generalizada. En segundo lugar, el valor de la USE es directamente proporcional a la formación, la habilidad y la experiencia del ecoendoscopista. Toda la información publicada sobre la USE se debe al trabajo de un grupo relativamente pequeño de expertos. En tercer lugar, cuando se emplea la USE para diagnosticar la pancreatitis crónica, la principal preocupación es la posibilidad de que se sobrediagnostique esta entidad, adjudicando falsos diagnósticos de PC a pacientes que carecen de enfermedad pancreática. Como los expertos no logran ponerse de acuerdo sobre el patrón oro del diagnóstico de la pancreatitis crónica, resulta difícil determinar el grado en que se está produciendo este sobrediagnóstico. En los pacientes que presentan evidencia de alteraciones de pancreatitis crónica en la USE, pero que tienen una prueba de la secretina normal o una CPER normal, no está claro si la ecografía endoscópica es más sensible a los cambios más precoces o si realmente está sobrediagnosticando una pancreatitis crónica (20).

En el pasado, varios estudios compararon la USE con otras modalidades diagnósticas. La comparación con las pruebas funcionales y la pancreatografía mediante CPER arroja resultados similares. La principal fuente de desacuerdo en estos estudios radica en los pacientes que obtienen resultados anormales en la ecografía endoscópica y pruebas funcionales normales o una CPER normal. Más recientemente se comparó la USE directamente con la prueba de la secretina. La prueba de la secretina se empleó como patrón oro en 21 pacientes con dolor abdominal de causa desconocida. Los dos ecoendoscopistas desconocían los resultados de la prueba de la secretina. Al utilizar un punto de corte de cuatro criterios para la pancreatitis crónica, la sensibilidad de la USE fue del $57 \%$ y su especificidad del 64\%. En todos los puntos de corte seleccionados, un número sustancial de pacientes presentaban resultados discordantes entre las pruebas (23).

En general, la histología es el candidato más evidente a ser el patrón oro del diagnóstico. En el caso de la pancreatitis crónica, varios factores han impedido la recogida de muestras histológicas. La distribución de las alteraciones de la pancreatitis crónica puede ser muy irregular (24). El tejido pancreático resulta difícil de obtener y la biopsia de páncreas se asocia a riesgos potenciales. ¿Podría desarrollarse 
alguna técnica capaz de diagnosticar fiablemente la pancreatitis crónica a partir de muestras de biopsia recogidas con aguja, en lugar de requerir resecciones quirúrgicas o muestras de biopsia incisionales? Hollerbach y cols. trataron de responder a esta pregunta (25). Evaluaron prospectivamente a 37 pacientes con síntomas clínicos y resultados analíticos indicativos de pancreatitis crónica. Todos los pacientes fueron sometidos a CPER, a pruebas de función pancreática indirectas (quimotripsina fecal, elastasa pancreática 1 fecal, pancreolauril urinario) y a ecografía endoscópica. Veintisiete fueron sometidos a aspiración con aguja fina (AAF) guiada por ecografía endoscópica. La CPER detectó una pancreatitis crónica en 31 pacientes y la ecografía lo hizo en 33. La ecografía endoscópica mostró una sensibilidad del 97\%, una especificidad del $60 \%$ y un valor pronóstico negativo del $75 \%$ al emplear la CPER como patrón oro del diagnóstico de la pancreatitis crónica. Los resultados de la AAF incrementaron el valor pronóstico negativo hasta el 100\%, dando lugar a un pequeño aumento de la especificidad hasta el $67 \%$. La correlación entre la ecografía endoscópica y las pruebas de función indirectas es escasa, sobre todo en los pacientes con afectación leve. Sobre la base de los resultados disponibles, no puede recomendarse la AAF como extensión rutinaria de la USE en el diagnóstico de la PC.

Actualmente, la USE constituye una herramienta importante para el diagnóstico de la pancreatitis crónica. Aún resulta controvertido el diagnóstico de la pancreatitis crónica precoz (de conductos pequeños) basado exclusivamente en los cambios observados en la USE. En tales casos, convendría tener en cuenta todos los componentes de la evaluación del paciente, incluidos la historia, las pruebas de función pancreática y la respuesta al tratamiento, antes de diagnosticar al paciente de pancreatitis crónica (20).

\section{TRATAMIENTO}

Los pacientes con pancreatitis crónica acuden al médico principalmente a causa de dos síntomas: el dolor abdominal y la maldigestión. Actualmente poseemos un tratamiento efectivo para la maldigestión, como son los suplementos de enzimas pancreáticas. Por otra parte, el tratamiento del dolor puede suponer un verdadero reto tanto para el médico como para el paciente. Se han propuesto tres mecanismos fisiopatológicos para explicar el dolor de la PC: a) la inflamación pancreática aguda; b) el aumento de la presión intrapancreática; y c) las alteraciones de los nervios pancreáticos. Los distintos tratamientos de la PC pretenden disminuir el dolor actuando sobre alguno de estos tres mecanismos. El tratamiento con antioxidantes trata de reducir la inflamación pancreática. Los suplementos de enzimas pancreáticas, los antagonistas de la colecistocinina (CCK) y el octreótido intentan disminuir la secreción pancreática y de esta manera reducir la presión intrapancreática. Diferentes técnicas endoscópicas y quirúrgicas tienen por objeto reducir la presión intrapancreática mejorando el drenaje. El bloqueo del plexo celiaco y la esplacnicectomía toracoscópica interrumpen la transmisión de las señales del dolor a través del nervio. Un abordaje radical y relativamente nuevo consiste en realizar una pancreatectomía con autotrasplante de células de los islotes. Pocos son los tratamientos que han sido realizados en ensayos controlados con placebo y que incluyan una muestra suficientemente amplia; los defensores de ciertos tratamientos concretos suelen olvidar que en estos pacientes puede observarse una sustancial respuesta al placebo, la cual puede llegar a ser del 35-40\% (26). A continuación trataremos del uso de los suplementos de enzimas pancreáticas, del bloqueo del plexo celiaco guiado por USE y de la pancreatectomía con autotrasplante de células de los islotes como tratamientos del dolor de la pancreatitis crónica.

\section{El papel de los suplementos de enzimas pancreáticas como tratamiento del dolor debido a pancreatitis crónica}

Es importante reconocer que la pancreatitis crónica no es una única enfermedad, sino que puede presentase de muchas formas. La distinción entre pacientes con pancreatitis crónica y afectación de grandes conductos y pacientes con pancreatitis crónica y afectación de conductos pequeños se hace con el fin de personalizar el abordaje terapéutico hacia estos diferentes grupos de pacientes (19). Al reconocer que un factor liberador de CCK desempeña un papel importante en el control de la secreción pancreática por retroalimentación, es probable que surja la idea de que pudieran existir formas de pancreatitis que estuvieran relacionadas con anomalías de la hemostasia de la CCK (27). Los preparados orales de enzimas pancreáticas parecen inhibir la secreción pancreática exocrina a través de un mecanismo de retroalimentación negativa en el que están implicadas las proteasas de serina intraduodenales y el páncreas exocrino. Las proteasas de serina intraduodenales modulan la secreción pancreática exocrina regulando la liberación de CCK. Como los pacientes con pancreatitis crónica suelen tener una reducción de la actividad de las proteasas de serina secundaria al daño glandular, podrían no ser capaces de inactivar el péptido intraduodenal (péptido liberador de CCK) que estimula los niveles sanguíneos de CCK. Por ello, en un subconjunto de pacientes, la glándula se ve constantemente estimulada por la CCK. Los suplementos orales de enzimas pancreáticas podrían aliviar el dolor al complementar la inactivación del péptido liberador de CCK por parte de las proteasas endógenas en los pacientes con dolor por pancreatitis crónica. La inactivación de este péptido da lugar a una disminución de la liberación de CCK, lo que disminuye la estimulación pancreática y, por consiguiente, podría reducir el dolor. Como este es un fenómeno que ocurre en el intestino delgado proximal, es obligado hacer llegar las proteasas pancreáticas a dicho intestino delgado proximal. Esto sólo puede lograrse repetidamente mediante la administración de preparados de enzimas pancreáticas con cubierta no entérica. Como los preparados enzimáticos con cubierta no entérica no están protegidos del ácido gástrico a su paso por el estómago, es conveniente añadir algún agente supresor del ácido (antagonista de los receptores $\mathrm{H} 2$ o inhibidor de la bomba de protones) para permitir que lleguen al duodeno cantidades significativas de proteasa. En nuestra experiencia clínica, hemos 
hallado que Viokase-16 (Axcan Scandipharm, Birmingham, $\mathrm{AL}$ ), administrado por vía oral a dosis de 4 comprimidos con cada comida y al acostarse, es el medicamento que logra la mejor respuesta clínica en la mayoría de los pacientes.

Seis estudios aleatorizados han evaluado la efectividad de las enzimas pancreáticas en el control del dolor de la pancreatitis crónica (28). Las enzimas pancreáticas resultaron efectivas para reducir el dolor en dos ensayos $(29,30)$, mientras que en 4 estudios no se observó ninguna mejoría estadística en cuanto a alivio del dolor. En virtud de lo que conocemos sobre la regulación de la secreción pancreática por la CCK y sobre el mecanismo de acción de las enzimas pancreáticas, no nos puede extrañar que los dos estudios que encontraron efectos positivos en cuanto a reducción del dolor utilizaran preparados con cubierta no entérica y que los que no hallaron ninguna mejoría utilizaran enzimas con cubierta entérica. Además, en los pacientes con afectación de conductos grandes, la tasa de respuestas en cuanto a reducción del dolor abdominal fue del $25 \%$ en el mejor de los casos, mientras que entre los pacientes con afectación de conductos pequeños hubo una tasa de respuestas aproximadamente del $70 \%$. Los resultados de un meta-análisis de estos estudios aleatorizados indicaron que el tratamiento con enzimas pancreáticas no disminuye el dolor abdominal de los pacientes con pancreatitis crónica (31). Sin embargo, este meta-análisis ha sido criticado por agrupar los análisis de los pacientes que recibieron enzimas con cubierta no entérica con los de quienes las recibieron con cubierta entérica (20).

Disponemos ahora de abundantes datos, procedentes tanto de estudios aleatorizados como de la experiencia clínica, que indican que los preparados de enzimas con cubierta no entérica son preferibles a los preparados con cubierta entérica para aliviar el dolor abdominal en los pacientes con pancreatitis crónica. Así, si se emplean preparados de enzimas pancreáticas para aliviar el dolor de la pancreatitis crónica, deben escogerse el paciente apropiado -es decir, uno con afectación de conductos pequeños- y el preparado de enzimas apropiado -es decir, un preparado enzimático con cubierta no entérica- a la dosis adecuada. No se logrará mucho si se intenta tratar el dolor de un paciente con afectación de conductos grandes y esteatorrea con un preparado de cubierta entérica.

\section{EI papel del bloqueo del plexo celiaco guiado por USE como tratamiento del dolor de la pancreatitis crónica}

Se ha acumulado una cantidad sustancial de bibliografía sobre el bloqueo del plexo celiaco guiado por USE en el tratamiento del dolor del cáncer de páncreas. Durante años se ha empleado una combinación de anestésicos locales de acción prolongada y de esteroides inyectada en el plexo celiaco de los pacientes con PC bajo guía ecográfica endoscópica (comunicación personal), pero los datos publicados son escasos. Gress F y cols. compararon el bloqueo celiaco guiado por USE con el bloqueo celiaco guiado por TC de forma prospectiva y aleatorizada (32). La conclusión de este pequeño estudio fue que el bloqueo celiaco guiado por USE ( $=10$ ) lograba un alivio del dolor más persistente que el del bloqueo guiado por TC $(n=8)$. El mismo grupo de investigadores publicó recientemente su experiencia prospectiva con el bloqueo celiaco guiado por USE en 90 pacientes con dolor a causa de pancreatitis crónica (33). Hubo una mejoría significativa de las puntuaciones de dolor en el $55 \%$ de los pacientes. El efecto beneficioso persistió más allá de las 12 semanas en el $26 \%$ de los pacientes y más allá de las 24 en sólo el $10 \%$.

La evidencia actual indica que el bloqueo del plexo celiaco guiado por USE es seguro y se tolera bien, obteniendo excelentes resultados temporales en algunos pacientes. Desgraciadamente, nos faltan factores fiables capaces de predecir el éxito. En ausencia de estudios a largo plazo con seguimiento de pacientes con pancreatitis crónica cuyo dolor sea crónico, el papel del bloqueo del plexo celiaco guiado por USE debe limitarse a tratar las reactivaciones del dolor crónico en aquellos pacientes que, por lo demás, tengan opciones terapéuticas limitadas.

\section{El papel de la pancreatectomía con autotrasplante de células de los islotes como tratamiento del dolor de la pancreatitis crónica}

Como tratamiento de la pancreatitis crónica grave, la pancreatectomía total logra un buen control del dolor, pero conlleva una importante morbilidad y mortalidad a largo plazo, sobre todo en relación con la diabetes mellitus resultante $(34,35)$. Una alternativa elegante consiste en realizar una pancreatectomía total o casi total seguida de un autotrasplante de células de los islotes. Este atractivo abordaje suscita grandes expectativas de lograr controlar el dolor al extirpar el páncreas enfermo sin pagar el precio de ocasionar una diabetes quirúrgica.

Recientemente, tres estudios han examinado la evolución de pacientes sometidos a pancreatectomía total seguida del autotrasplante autólogo de células de los islotes. Se intervino a 22 pacientes en la Universidad de Cincinnati entre febrero de 2000 y febrero de 2003 (36). Hubo 4 complicaciones postoperatorias importantes (síndrome de dificultad respiratoria aguda, absceso intraabdominal y embolia pulmonar) y ninguna muerte. Todos los pacientes tomaban analgésicos opioides antes de la intervención. Tras un seguimiento medio de 19 meses (intervalo de 3 a 41), el 82\% de los pacientes ya no precisó ninguna analgesia con opioides. El $41 \%$ eran insulinoindependientes y el $27 \%$ requerían cantidades de insulina mínimas.

Recientemente se publicó la experiencia del Leicester General Hospital del Reino Unido (37). Cuarenta pacientes fueron sometidos a pancreatectomía con autotrasplante de células de los islotes. El intervalo de seguimiento fue de 6 meses a 7 años. El control del dolor se estimó de forma grosera según el uso de opiáceos comunicado. No se dispuso de datos sobre todos los pacientes. A los 6 meses, todos los pacientes con datos disponibles $(n=6)$ seguían necesitando narcóticos. Esa cifra disminuyó a 5 de 10 pacientes al año, y a 4 de 9 pacientes a los dos años. De los 4 pacientes seguidos durante 6 años, uno seguía necesitando opioides. Lo más importante es que, de los 40 pacientes, 38 precisaron 
distintas dosis de insulina y sólo uno presentó una prueba normal de tolerancia a la glucosa por vía oral. Los autores observaron que la función del trasplante de células de los islotes se iba deteriorando con el tiempo.

La serie más amplia publicada hasta la fecha procede de la Universidad de Minnesota (38). A lo largo de un periodo de 28 años se realizaron 112 autotrasplantes de células de los islotes al tiempo que una pancreatectomía total o subtotal para tratar la pancreatitis crónica. El dolor se resolvió en el $40 \%$ de los pacientes, mejoró en el $32 \%$ y permaneció igual o empeoró en el 12\%. Se logró una total independencia de la insulina en el $38 \%$ de los pacientes y el $12 \%$ precisaron sólo una inyección diaria de insulina de larga duración. Además, no requirieron insulina el $71 \%$ de los pacientes que no habían sido sometidos previamente a cirugía pancreática. No resulta sorprendente que los pacientes previamente sometidos a pancreatectomía distal o drenaje de Puestow tuvieran menos células de los islotes y que menos del $20 \%$ lograran no depender de la insulina.

Estos estudios muestran que el autotrasplante de células de los islotes es técnicamente factible. Según vaya mejorando esta tecnología, puede que un día la pancreatectomía total seguida de autotrasplante autólogo de células de los islotes se convierta en el tratamiento habitual de los pacientes que padezcan dolor refractario a causa de una pancreatitis crónica.

\section{CONCLUSIÓN}

La patogenia de la pancreatitis crónica idiopática sigue siendo poco conocida. Las mutaciones genéticas explican una minoría de los casos de pancreatitis crónica idiopática. El verdadero valor de la ecografía endoscópica para diagnosticar la pancreatitis crónica de conductos pequeños está por terminar de definir. Los suplementos de enzimas pancreáticas de cubierta no entérica constituyen un tratamiento efectivo para los pacientes con pancreatitis crónica de conductos pequeños. El bloqueo del plexo celiaco guiado por ecografía endoscópica puede lograr un excelente alivio del dolor a corto plazo en algunos pacientes con pancreatitis crónica. Se necesitan estudios controlados amplios y a largo plazo que examinen la seguridad y la eficacia del bloqueo del plexo celiaco. Actualmente, su uso debe limitarse a aquellos pacientes cuyo dolor no responda a otras modalidades. La pancreatectomía total seguida de autotrasplante autólogo de células de los islotes parece un abordaje terapéutico factible, pero por ahora debe considerarse como experimental. 